\title{
Justifying Communal Violence, Recuperating Militancy: Sunil Ariyaratne's Sarungale and Gamini Fonseka's Nomiyena Minisun $^{1}$
}

\author{
Nalin Jayasena \\ Miami University, USA
}

\begin{abstract}
This paper examines two Sinhala films, Sunil Ariyaratne's Sarungale(1979) and GaminiFonseka'sNomiyenaMinisun (1994), that demonstrate the ambivalence of the Sinhala socio-political establishment towards the Tamil other. However, while Ariyaratne's ambivalence is discriminatory and victimizes the Tamil minority, Fonseka's recuperation of Tamil militancy provides the potential for change in a post-conflict society.
\end{abstract}

InSarungale, Ariyaratneemploys a perspective in which intra-ethnic violence (caste-based violence amongst Hindu Tamils) is juxtaposed with inter-ethnic, communal violence between Sinhalese and Tamils. In so doing, the film justifies anti-Tamil violence experienced by Nadaraja, the Tamil protagonist. However, by casting GaminiFonseka, an icon in Sinhala cinema in the role of Nadaraja, and by using the popular genre of melodrama, Ariyaratne elicits the viewer's sympathy towards the victimization of Tamils. Indeed, it is this type of vacillation towards Tamils, and by extension the Tamil national question, since the 1950s that gives rise to Tamil militancy and the armed conflict of the 1980s.

Regarding Sri Lanka's armed conflict, much critical attention has been paid to the state's violent suppression of resistance, and considerably less scholarship is devoted to the state's complex relationship to Tamil militancy. Indeed, the reincarnation of former combatants as new stakeholders in the government has challenged static definitions of militants, an identity often conflated with "terrorists". At the same time, however, the state has made arbitrary distinctions between militants by requiring rehabilitation of some cadres and not others.

\footnotetext{
1 I would like to acknowledge the two anonymous reviewers for their astute comments on an earlier draft of this essay and for the unfailing support and guidance of Carmen Wickramagamage, Editor.
} 
My argument, then, consists of two claims: on the one hand, the ambivalence of Sarungale illustrates the discriminatory power of majoritarian politics evident even in its progressive aesthetic expressions. Indeed, it is this form of discriminatory power disguised as humanism that leads to total war. On the other hand, NomiyenaMinisun represents a productive form of ambivalence as the film captures the state's mutable position vis-à-vis the Tamil militant movement, an inconsistent logic that gives a faint ray of hope for post-war reconciliation in Sri Lanka.

Keywords:Tamil militancy, victimhood,discrimination, aesthetic expression

"The function of ambivalence [is] one of the most significant discursive and psychical strategies of discriminatory power." Homi Bhabha

The title of this essay foregrounds a conflicting logic: collective violence against minority communities, a specific focus of Sarungale (1979) and indefensible under most circumstances is not categorically rejected but indirectly condoned; on the other hand, militant violence as depicted in Nomiyena Minisun (1994), a phenomenon routinely aligned with terrorism and insurgency in Sri Lanka and in the contemporary world, is redeemed and humanized. ${ }^{2}$ Using this contradictory logic as a framing device, I suggest that the two films reveal an ambivalence about Tamil subjects, both civilian and militant, not only in the battle-hardened and ethnically polarized 1990s but also in the pre-war 1970s. However, while one form of ambivalence is discriminatory and victimizes the minority community, the other form offers the "potential" for political and social progress by rejecting totalizing notions of militancy. More specifically, Sunil Ariyaratne's Sarungale gives us a Tamil protagonist in the form of Nadaraja, who is both pitied and punished during the course of the film; played by Gamini Fonseka, an iconic figure in Sinhala cinema, Nadarajah may be the only Tamil protagonist in Sinhala cinema. ${ }^{3}$ Though this fact alone

2 In the course of this paper, I examine how certain forms of Tamil militancy have been absorbed into the political mainstream and have become normalized. In the wake of the anti-Muslim pogrom in Aluthgama in June 15, 2014, the same may be said of the recurrence of communal violence and the state's predictable response towards it.

${ }^{3}$ In saying so, I am not including stereotypical portraits of Tamils in mainstream films like Nihal Silva's Sargent Nallathamby (1990), based on one of the most popular stage plays of the 1980 s. 
implies Ariyaratne's desire to humanize Tamil identity, Nadarajah's portrayal of an orthodox Hindu who is bound by caste divisions, undermines its progressive potential. On the other hand, Gamini Fonseka's Nomiyena Minisun, a film made in the wake of a decade of fighting between the Government of Sri Lanka and several groups of Tamil militants, recuperates the latter and confounds claims that conflate militant movements with terrorism; however, as the film attempts to humanize one group of Tamil militants, it also demonizes other militants, while emphasizing an ethnocentric link between Sinhalese and North Indians at the exclusion of Tamils. These conflicting narratives, I suggest, reflect the ambivalence of the Sinhala cultural and political establishment vis-a-vis the national question.

As the passage from Homi Bhabha illustrates, ambivalence functions as the basis for "discriminatory power," an insight not confined to the colonial world but includes "racial or sexist, peripheral or metropolitan" political contexts as well (66). Applied to the ethno-nationalist context of Sri Lanka, it means that SinhalaTamil relations are defined by a conflictual economy ${ }^{4}$ that functions differently in the two Sinhala films in question. It is an understatement to say that Sarungale is preoccupied with caste. In the world of the film, the key distinction between Tamil and Sinhala communities is the presence (or absence) of the caste system. Tamilness is intimately linked to caste and therefore insular. The Sinhala community, on the other hand, is free from the social stigma instilled by the caste system and is deemed liberal and progressive. However, this dualistic view of communal relations is complicated by the anti-Tamil sentiment ascribed to segments of the Sinhala community. This is also what makes The Kite an example of ambivalence: on the one hand, the film's conception of caste renders the Tamil subject deviant from Sri Lankan (i.e. Sinhala) norms; on the other hand, in the face of anti-Tamil violence, the viewer is invited to identify with the Tamil as victim. Finally, this identification with the Tamil victim of violence is, in turn, modulated by the violence associated with caste discrimination. Thus Sarungale is an apt illustration of the link between ambivalence and discrimination and the yet-to-be resolved problem of the national question.

\footnotetext{
4 The aim of this essay is not to equate colonial dynamics with communal politics in Sri Lanka. Nonetheless, Bhabha's concept of ambivalence, as a hermeneutics of power and discrimination lends itself effectively to the filmic texts I consider here.
} 
At face value, Nomiyena Minisun pays homage to the Sri Lankan (i.e. Sinhala) soldier, as the immortality invoked in the title refers unambiguously to the defenders of the nation. Unlike in Sarungale, this film attempts to exclude the Northern Tamil civilian from the national imaginary, whose place is occupied by several Indian characters and by a host of Tamil militants. Fonseka employs the Indian characters to serve two mutually exclusive objectives: first, they help the film recuperate India's role in the Sri Lankan armed conflict and second, they facilitate the film's hero, Colonel Ranabahu's condemnation of the state of Tamil Nadu for sponsoring Tamil militancy in Sri Lanka. Further obscuring these conflicting trajectories, the film also features a significant subplot that humanizes Tamil militants, making the film unique amongst mainstream Sinhala cinema. In Nomiyena Minisun, then, Gamini Fonseka's ambivalence centres on his inconsistent stance on Tamil militancy, which I argue parallels the Sri Lankan state's contradictory position vis-a-vis the Liberation Tigers of Tamil Eelam (LTTE) that culminates in a process called "rehabilitation."

\section{From Intra-communal Violence to Inter-communal Violence}

Released in 1979, Sunil Ariyaratne's Sarungale is supposedly the first Sinhala feature film to explore Sri Lanka's ethnic conflict. While Sunil Ariyaratne directed the film, an iconic actor in Sinhala cinema, Gamini Fonseka, is credited with the story and he goes onto play the leading role of Nadarajah. According to Sinhala film critic Jeewantha Dayananda, Fonseka had witnessed the anti-Tamil riots of 1958 first-hand, which then became the basis and inspiration for the film. In Profiling Sri Lankan Cinema, Wimal Dissanayake and Ashley Ratnavibhushana hail Sarungale as "an attempt to rethink this conflict in more human terms" (78). Dissanayake's and Ratnavibhushana's emphasis on the film's humanism was reiterated by viewers who identified Gamini Fonseka's humanizing portrayal of Tamil subjectivity. In the opinion section of the Sinhala newspaper Silumina, Dayasena Gunasinghe writes, "Sarungale depicts universal humanity." Likewise, . in the popular entertainment magazine Sarasaviya, State and Media Minister Ananda Tissa de Alwis observes that Nadarajah's character unites all ethnic groups living in Sri Lanka. (15) This paper, on the other hand, suggests that the overly positive reviews of Sarungale, a film about the ethnic conflict, reveal the failure of Sinhala audiences to recognize and relate to the predicament of the Tamil minority in late-1970s Sri Lanka and account for the persistence of the national question that has haunted the nation since independence. 
The film proper begins in a low-income, mudukku, neighbourhood in Colombo where Nadarajah, à government clerk, rents a house. He has a close friendship with Simon who runs a teashop where he also sells moonshine on the side. Nadarajah has a strong affinity for Simon's daughter, Wasantha. One day, Wasantha asks Nadarajah to buy her a kite. This innocent request triggers a series of flashbacks that take the viewer twenty years back to Jaffna, where Nadarajah had once lived with his grandmother and sister, Thangamani. One day he tells Thangamani that he will look for a suitable groom for her; he tells her that she can marry a non-Tamil man as long as she marries within her caste. At the same time, Nadarajah has a close friendship with Mr. Jayasekera, a Sinhala co-worker whose daughter, Sushila, begins to develop romantic feelings towards Nadarajah. However, Nadarajah's desire to marry Sushila is thwarted by her mother on the basis that he is Tamil. In the mean time, Thangamani falls in love with a low-caste man named Rasan. When Nadarajah discovers her affair, he assaults Rasan but fails to end their relationship. Soon thereafter, Thangamani discovers that she is pregnant with Rasan's child and commits suicide. This tragedy and the loss of his love propel Nadarajah to flee Jaffna and to relocate to Colombo where, by the melodramatic end, he falls victim to Sinhala mob violence.

Time and again, Sarungale has been lauded as an exemplary study of the communal conflict and such interpretations are not completely baseless. As noted above, no Sinhala film that explores the ethnic conflict employs a Tamil character as its protagonist. Gamini Fonseka who plays the protagonist was one of the most popular Sinhala actors at that time, which would make a predominantly Sinhala audience identify with the character through their loyalty to one of the brightest stars in the local cinema. However, despite the centrality of a Tamil character to the film's plot and the casting of an iconic film star, Nadarajah's characterization highlights the Tamils' deviation from normative "Sinhala values" and the irreconcilable cultural gap separating the two communities. Symptomatic of this disjuncture is the film's preoccupation with the Tamil caste system, which is revealed in the film's opening frame that introduces Nadarajah to the viewer. Following the opening credits, the film begins quite unexpectedly with a non-diegetic voice-over 5 that introduces a still image of Nadarajah: "Although he rejects ethno-centric views, he adheres to

${ }^{5} \mathrm{~A}$ non-diegetic voice is one that does not belong to a character in the film's narrative and is, therefore, external to the world of the film. 
the caste system that is integral to his identity as a Tamil." After introducing Thangamani and Rasan, we see the still image of Simon followed by the same voice-over: "Though his appearance is rough and his language crude, he is a kind-hearted Sinhala man who rejects retrograde views." In this didactic introduction, the film's portrayal of Nadarajah's caste-consciousness is inseparable from Tamilness, an ethnic stereotype that I will discuss in detail below. What is equally problematic is that Simon's introduction as a man who rejects insular views sets up an opposition between the retrograde Tamil and progressive Sinhala characters. Beginning with this opening frame, the pairing of Sinhala and Tamil characters who espouse conflicting values views is a recurrent pattern that the film adopts. Although the voice-over never returns to the film, its omniscience grounded in its position outside of the narrative leaves a lasting impression on the viewer and contributes to an uneven and conflicting perception of the Sinhala and Tamil communities represented by these two characters. I propose that it is this antithetical relationship between the characters that paves the way for the film's denouement where Nadarajah is killed and Tamilowned property is destroyed.

Ariyaratne, however, does not examine the Hindu caste system with the aim of social reform but as a means to recuperate anti-Tamil sentiments of the Sinhala community. In other words, Sarungale employs a comparativist perspective in which intra-ethnic violence (such as Nadarajah's public beating of Rasan) is juxtaposed with inter-ethnic, communal violence (the violence experienced by Nadarajah and other Tamils in the South). In so doing, the film implies a causal relationship between casteism in Jaffna Tamil society and anti-Tamil violence in Colombo. This, I argue, is one reason why a narrative inquiring into the national question become so preoccupied with question of caste.

To highlight the parallel structure that Ariyaratne employs to broach the issue of caste, I will examine two scenes from Sarungale; each scene features Nadarajah and a Sinhala character debating the issue of caste. In the first scene, we find Nadarajah and his coworker, Gunay, walking to work. Gunay remarks, "I read in the paper this morning that there was a shooting in Jaffna." But Nadarajah dismisses this report as an example of "dirty politics."

Gunay: Maybe so, very sad news, anyway. (After a brief pause in the conversation) Can this problem of caste be stopped? 
Nadarajah: That comes from the Hindu religion. Now, I wish it didn't hold sway over our community. But what is the point if I am the only person who thinks that way?

Gunay: Oh, yes. Oh, yes, that is true. The whole community must think as one.

Nadarajah: That's right. Your community is very developed. You all don't have a caste system, do you?

At a basic level, both the Sinhala and Tamil characters agree that caste is a social evil, although Nadarajah begins his response with a justification for Tamils' caste consciousness rooted in religion. Thereafter, Nadarajah's statement that "now" he is critical of caste implies that he had once held a different view about it. Later, via the flashback, when we consider his life in Jaffna, we learn that he was once an apologist for the caste system. Not only does this scene make explicit the film's preoccupation with caste, it can also be used to bring caste and violence together. While the type of violence in Jaffna is not specified, Nadarajah's reference to politics suggests that it involves political violence. Gunay for one seems to suggest that the violence is connected to the Hindu caste system. Indeed the sequence, from an instance of violence in Jaffna to caste consciousness, suggests that the two contiguous topics are actually ideologically linked. What, then, is the basis for Sarungale to link political violence and the issue of caste?

The next instance caste is mentioned in the film is in a flashback, which narrates Nadarajah's life in Jaffna 20 years in the past. This extended flashback that lasts about 40 minutes of running time begins with a scene between Nadarajah and his friend, Mr. Jayasekera, who are walking side-by-side with the Jaffna fort looming in the background.

Jayasekera: (In an exasperated tone) I don't know where the concept of caste came from. Now look, Mr. Nadarajah, my wife belongs to one caste and I belong to another caste. What matters is our common humanity (manussakama).

Nadarajah: Mr. Jayasekera, caste is an important element of society but communal divisions, between Sinhalese and Tamils, must be abolished.

Jayasekera: I am absolutely opposed to it. There is no such thing as caste, Mr. Nadarajah. We are all the same. Why do we divide ourselves in this way? 
In this scene, we find a dynamic similar to what we identified in the opening scene of the voiceover. The former marks the beginning of the film while the latter inaugurates an extended flashback 20 years in the past. The difference is that in this scene, two characters belonging to two ethnic groups articulate conflicting ideologies, which then become representative of each group. Jayasekera's condemnation of caste renders him progressive, which the film links to having compassion (manussakama); this means that the young Nadarajah who champions caste as a core principle of Hindu society is associated with the past (and visually reinforced by the dilapidated Dutch fort that looms in the background) but more importantly, this renders him devoid of compassion and humanity.

While it is true that caste is a crucial component of orthodox Hinduism (as Nadarajah informs Jayasekera), what is of concern is the film's portrayal of Tamils exclusively through the lens of Hindu orthodoxy, while the Sinhalese are not similarly yoked to Buddhism. But if Ariyaratne imagines Hindu Tamil subjects purely through the lens of caste, he is not alone in doing so. Rather, it is a common trope associated with Tamil subjectivity, even amongst Tamil authors. A good example is Ambalavaner Sivanandan's When Memory Dies, which depicts Jaffna society torn apart by caste while caste is a non-issue in Colombo, the setting for much of the novel. Another example from Sri Lankan cinema is the Tamil film Ponmani (1978), based on the screenplay by Tamil author Kavaloor Rajadurai; not unlike Sarungale, it is a story about the social upheaval caused by an inter-caste relationship in Jaffna. To some extent, then, this bifurcated view of Sinhala and Tamil societies and their relative caste consciousness lies in colonial discourse, which viewed Sinhala society through the supposedly caste-free lens of Buddhism. But is Sinhala Buddhist society actually free from the taint of caste? This is the very issue that Nadarajah raises with Gunay, though in that scene, Nadarajah already seems to believe that the Sinhalese are liberal and cosmopolitan.

Although Sarungale has the viewer believe that caste is not a salient factor in Sinhala society, this is a claim that is refuted by historical precedent and by established scholars in the field. Commenting about colonial Ceylon Nira Wickramasinghe writes, "Village disputes, which were only very rarely of a violent nature, arose from issues pertaining to land, women and caste status. Caste discrimination was a reality" (112). Though caste was not the basis for violent attacks, it was not invisible either. Wickramasinghe's 
insight goes beyond her work's immediate focus on the $1920 \mathrm{~s}$. Another well-known instance of Sinhala society's caste consciousness is in the election of Ponnambalam Ramanathan to the Legislative Council of Ceylon in 1911 over a lower caste Sinhalese candidate. For the educated and wealthy Sinhalese at the turn of the century, class solidarity trumped caste prejudice. Writing of contemporary Sri Lanka, Kalinga Tudor Silva remarks, "In Sinhala society, the lower the caste status the more excluded they were from power, land ownership, and sources of honour and human dignity" (4). In other words, one's caste status determined one's social mobility. Though caste discrimination was not exercised via religious injunction, as it was 'for Hindu Tamils, "Buddhist organizations in Sri Lanka had adopted caste as a principal of social setup among Buddhist monks and exploited it for mobilizing ritual services and extracting surplus from temple property" (4). Not unlike in Sarungale in which Nadarajah insists that his sister marry within their caste, caste is an important consideration in middle-class Sinhala marriages, especially arranged marriages, as is evidenced by a brief glance at matrimonial advertisements in both Sinhala-language and Englishlanguage newspapers which reveal a clearly defined caste hierarchy.

If caste and ethnicity are interdependent social issues, a point underscored by the scene between Nadarajah and Jayasekera, could one community's caste prejudice justify another community's ethnic prejudice? Although anti-Tamil violence in the South is one of the film's major concerns, Ariyaratne's decision to employ a Jaffna Tamil (as opposed to a Colombo Tamil) further reinforces the parallel the film creates between North and South, Tamil society and Sinhala society. What prompts Nadarajah to relocate from Jaffna to Colombo is his sister's suicide, a direct consequence of Nadarajah's caste prejudice. However, it is a fact of history that had Nadarajah remained in Jaffna, he would not have found himself in the crosshairs of anti-Tamil violence. By leaving Tamil society and entering a predominantly Sinhala space, he seems to give tacit consent to anti-Tamil violence. In the communal violence of 1958 , Tarzi Vittachi notes that in Jaffna, Tamils retaliated against Sinhalese; this means that in predominantly Tamil spaces, Tamils were not passive victims but defended themselves aggressively against violence. Thus Nadarajah's flight from Jaffna and his arrival in Colombo seem to be a form of self-inflicted punishment, one sanctioned by the narrative for his own insular views about Tamil 
society. This is the corollary of linking caste and ethnic prejudice. However, implicating Nadarajah in the anti-Tamil violence that ultimately claims his life is tantamount to blaming the victim, ${ }^{6}$ a phenomenon with a longer political history, which goes beyond the ethnic conflict in Sri Lanka.

Writing of the German composer Richard Wagner's anti-Semitism, Theodore Adorno accuses Wagner of having bated his Jewish conductor Herman Levi so that Wagner could blame his subsequent criticism. of Levi on his Jewishness. For Adorno this form of deflection "bears witness to the existence of one of the most sinister features of the Fascist character even in Wagner's time: the paranoid tendency of projecting upon others one's own violent aggressiveness and then indicating, on the basis of this projection, those whom one endows with pernicious qualities" (qtd. in Harding 143). The "violent aggressiveness" that characterized the Sinhala responses to Tamil demands for equality dates back to the 1950 s. $^{7}$

Though the attempted link between caste prejudice and ethnic prejudice result in disastrous consequences for Tamils in the film, Sarungale isn't devoid of a vision of inter-communal harmony. To be fair to Sunil Ariyaratne, his film makes an attempt to represent Sinhala prejudice through Sushila's thwarted romance with Nadarajah. While Sushila's father, Mr. Jayasekera, supports his daughter's romance, her mother's staunch opposition is based on the impracticality of an inter-ethnic marriage. Subsequently, Sushila's mother scuttles the budding romance by proposing marriage between Sushila and a distant Sinhala relative from Anuradhapura (which is not a coincidence). Ariyaratne's solution to bridging the ethnic divide does not end with Mr. Jayasekera's egalitarian statement rejecting caste and ethnic divisions, as the film indulges in a fanciful and upbeat sequence that depicts an imaginary marriage ceremony between Nadarajah and Sushila. What is striking about this almost-whimsical sequence that lasts close to 5 minutes is that the bride and groom observe both Sinhala and Tamil marriage rituals and in so doing the film evokes

\footnotetext{
${ }^{6}$ The best illustration of this was the government's response to the anti-Tamil violence of 1983, which was blamed on the Tamils. Both President J.R. Jayawardene and Prime Minister Ranasinha Premadasa link Sinhala violence to acts of Tamil militancy (both real and imagined). See Gananath Obeysekera, "Origins and Institutionalization of Political Violence" 167-68.

${ }^{7}$ See Tambiah for details about the Sinhala response to the Tamils' satyagraha (non-violent protest) against S.W.R.D. Bandaranaike's Sinhala-only policy.
} 
thepromise and possibility of a bi-cultural union that refuses to subsume one identity to another.

Since this idealistic sequence is conjured in the minds of a young couple smitten by desire, it has a tenuous relation to reality. The happiness invented by the imaginary sequence is short-lived as Nadarajah is dealt a double blow: Sushila's family leaves Jaffna abruptly and Thangamani commits suicide. If the insularity of the upper-caste Tamil is implicated in Thangamani's death, what then is the punishment for Sinhala chauvinism in the North (embodied by Sushila's mother's opposition to Nadarajah) and the more prominently displayed chauvinism in the South that culminate in collective violence ${ }^{8}$ We learn that Sushila's mother's anti-Tamil prejudice has deprived Sushila of true happiness which is conveyed in a scene in which Sushila and Nadarajah are reunited briefly in a café against the backdrop of anti-Tamil violence. In this scene, Sushila confesses to Nadarajah that she is deeply unhappy in her marriage. However, this scene that depicts the consequences of Sushila's mother's prejudice is filmed against the backdrop of antiTamil violence in Colombo, not to establish some continuity between the two, but to suggest that Sushila's mother may be right. In other words, this scene suggests that had the two married, Sushila would have had to rescue Nadarajah from violence, as she must do in this scene by hastily erasing his pottu and the ash mark and declaring to the mob that he is her husband. Second, anti-Tamil sentiments in the South cause widespread damage to Tamil-owned property which is depicted through a montage of shots of destroyed homes, retail businesses, office buildings, and burnt out vehicles. While Nadarajah's prejudice leads to his sister's suicide, and indirectly to his own demise by his decision to live in Colombo, Sinhala prejudice results in the unhappiness of one Sinhala character (Sushila) and extensive damage to Tamil property and the loss of numerous Tamil lives. While it could be argued that the effects of violence are not quantifiable, what is problematic is that in Sarungale anti-Tamil violence is nebulous and muted, because we rarely see the agents of that violence. During the rare instances when we do see the agents of violence (that too is a fleeting image of thugs pursuing Nadarajah), they are aligned with the outcasts of Sinhala society, the lumpen proletariat.

\footnotetext{
${ }^{8}$ By juxtaposing the two I am analyzing the film by its own terms. That is, the parallel I draw here is reflected in the very structure of the film.
} 
In his famous essay, "The Open Economy and Its Impact on Ethnic Relations in Sri Lanka," Newton Gunasinghe has suggested an economic dimension to the anti-Tamil violence. In the riots of 1977 and 1983, chauvinist elements in the Sinhala establishment manipulated the economic frustrations of the urban poor and channelled their anger towards the Tamil community. While Gunasinghe's is an intellectual argument based on sociological data, Sarungale seems to use the Sinhala working classes as a backdrop for narrating Nadarajah's life in the South. It is peculiar, but not entirely a coincidence, that Nadarajah elects to live in a slum surrounded by the urban poor. While Gunay, Nadarajah's coworker, who holds a subordinate position to Nadarajah at their government job, lives in a modest lower middle-class home, Nadarajah separates himself from his own ethnic and class backgrounds by living amongst the lumpen proletariat. By choosing to live in this undesirable environment, is Nadarajah punishing himself for his insular views about his own people? If he exits Jaffna to escape its oppressive caste hierarchy, what is he escaping by living amongst Colombo's slum dwellers? Even in this new environment, he makes no effort to blend. Rather, Nadarajah cuts a striking figure in his white suit and tie and solar topee as he walks in and out of a neighbourhood comprising shanties. Unlike his social equals, such as Gunay, at no point does Nadarajah ever cast aspersions on his proletariat neighbours. On the contrary, he defends them as good people and it seems that Nadarajah is indifferent to social class. In a previously cited conversation between Gunay and Nadarajah, we noted how the latter has changed his views about caste. Nadarajah's progressive views about social class are part of his "growth" into a righteous character. However, one nagging question remains: why is Nadarajah's righteousness linked to his continued suffering?

Migrants settle down and live where they can fit in, not where they stand out, isolated and alone. The same applies to internal migrants like Nadarajah. Not only because of his middle-class appearance but also because he has no social outlets in Colombo, Nadarajah stands out in this environment. Though Simon looks up to Nadarajah, there is little social interaction between them. Yet again, this begs the question: why does Nadarajah avoid his social equals, both Tamil and Sinhala? While we may surmise the reason why he keeps away from Colombo's Tamil enclaves, it makes little sense that he keeps the Sinhala middle class at arm's length as well, especially since his only adult friend in Colombo is Gunay, his Sinhala co-worker. One 
exception to this norm is Simon's daughter, Wasanthi. Nadarajah's friendship with Wasanthi is the only ray of light in his otherwise desultory life in Colombo. Their bond is built along filial lines: she calls him uncle and he calls her daughter. For Nadarajah, Wasanthi fills the void left by Thangamani's death. For Wasanthi, Nadarajah repairs old kites and sometimes buys new kites and it is through these kites that the film links Colombo to Jaffna, the present to the past. Despite this brief respite in his humdrum existence, his life in Colombo is spent in mourning for his past. This is illustrated early in the film when Nadarajah notices on the streets a random Tamil couple that reminds him of Thanga and Rasan. In the very next scene, when Nadarajah returns home, the film underscores his despondence by depicting a man with downcast eyes ambling home to a soundtrack consisting of a slow, doleful tune. Here is proof that Nadarajah fled Jaffna to escape memories of Thangamani that, in this instance, continue to follow him; moreover, his austere life in a ramshackle cottage surrounded by men and women of a different ilk is the price he must pay for his misdeeds in Jaffna. If by living amongst the uneducated and under-employed, Nadarajah hopes to make amends for his past misdeeds, the filmmaker's choice of setting facilitates a paradoxical portrait of the Sinhala poor, namely Simon, who epitomizes the film's ambivalence about Tamil subjectivity and by extension the national question.

True to the non-diegetic voice-over of the opening, Simon is perhaps the only character free from self-serving motives and has the clearest conscience, except when he is intoxicated. Although during the course of the film, Simon saves Nadarajah's life twice from the mob, under the influence of kasippu (moonshine), he is prone to the worst anti-Tamil diatribe. This invective is not generic but directed specifically at Nadarajah-a man for whom Simon has the utmost respect when sober. Of course, by the morning after Simon has no recollection of the previous night's debauchery; when he learns of his misdeeds from his wife, Simon begs forgiveness from Nadarajah. Simon's verbal assaults are not meaningless rhetoric induced by alcohol, as he invokes a popular idiom in Sinhala nationalist history. For instance, in one scene, Simon compares himself to Dutugemunu who felt trapped between the 'mute ocean' on one side and Tamil invaders on the other. Like Dutugemunu, Simon sees himself trapped between Nadarajah (i.e., the Tamil invader) and the police who can arrest him for selling illicit liquor. On the one hand, Simon's ethno-centric rhetoric gives voice to Sinhala nationalist sentiments that would be shared 
amongst a segment of the film-viewing public. On the other hand, like Simon's recanting the morning after, the filmmaker is able to disavow his own fears and doubts about the Tamil community by displacing it into an alcohol-induced diatribe. Perhaps this is one reason Simon has a clear conscience; he can deny any knowledge of his misdeeds and attribute all his flaws to alcohol instead. This divided conscience (of both loving and hating Nadarajah) attributed to a "good-hearted" Sinhala man represents Tamilness as other (a deviation from the normative Sinhala subject); more importantly, it betrays the filmmaker's conflicted emotions towards Tamil subjectivity.

On the day when anti-Tamil violence is sweeping through Colombo, Simon makes a valiant effort to prevent Nadarajah from going to work but to no avail. Later that night when Nadarajah staggers home, Simon first mistakes Nadarajah's brutalization at the hands of the mob for his intoxication.

Simon: Looks like Mr. Nadarajah is coming. (Close up of Simon and his wife, their faces reflect their sense of relief. Cut to a long shot of the lane that reveals Nadarajah zigzagging towards Simon). The man who advised me against drinking is himself completely drunk (Simon chuckles but then his expression begins to change as Nadarajah comes closer and collapses).

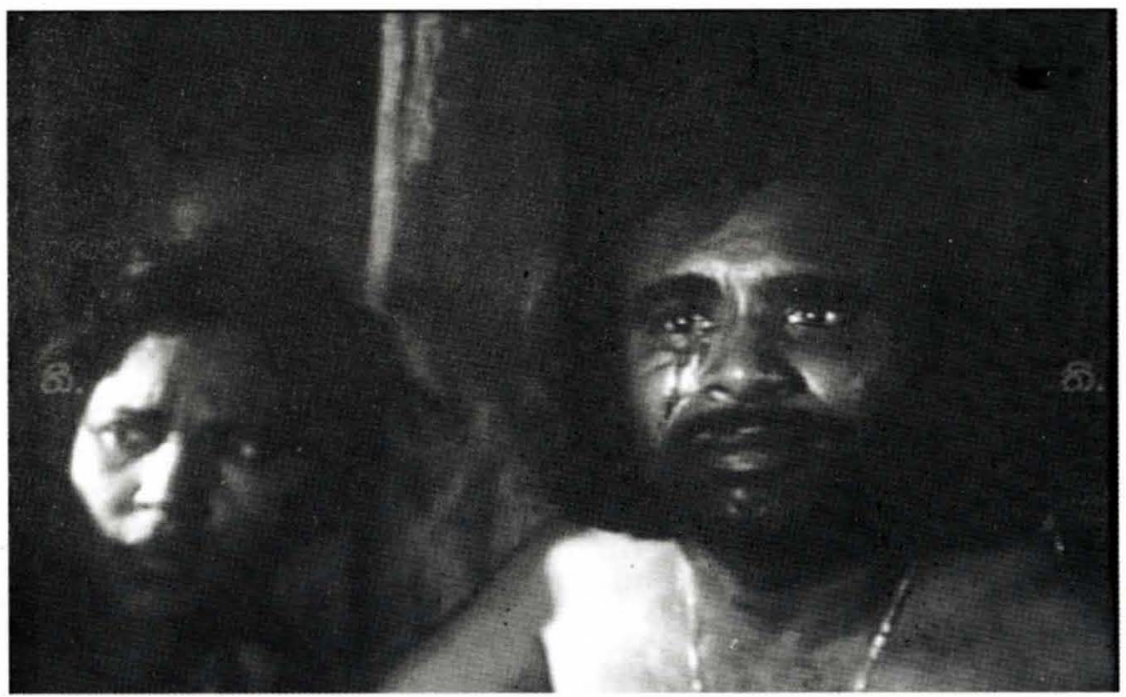

Figure 1: Simon's expression begins to change 
The same alcohol that brings out Simon's suppressed prejudice, he thinks, has for once taken hold of Nadarajah; the truth is that he has fallen victim to racist thugs. The result is a disturbing juxtaposition between racism induced by intoxication and violent victimization mistaken for intoxication. Its corollary is that alcohol is both an alibi for ethnic prejudice and a filter by which the effects of prejudice are diluted, the sum total of which is to minimize the socio-political impact of anti-Tamil prejudice. Finally, the shift in Simon's mood from relief to amusement and finally to concern, parallels the film's vacillation between humanizing and dehumanizing Nadarajah.

However, once Simon realizes the extent of Nadarajah's injuries, he becomes emotional. When Nadarajah notices Simon crying, he speaks to Simon in Tamil for the first time: "your tears prove your love for me." This is a powerful (if melodramatic) moment in a film where a transplant from Jaffna who speaks in a translated tongue for most of the film switches to his own language. Tamil is spoken in the film only amongst Tamil characters, and that too in Jaffna. By making Nadarajah's last words Tamil the film suggests that he has reconciled himself with his past. However, his words themselves suggest a different meaning. Nadarajah's last words affirm Simon's affinity to him but it also reveals Nadarajah's deep-seated desire for acceptance. The very possibility of not loving (or loathing) Nadarajah, who, before falling victim to mob violence, had been a surrogate father to Simon's daughter Wasanthi and who, on one occasion, had bailed Simon out of jail, reveals not Nadarajah's humanity but his liminal status in Colombo. Though as a government servant he is the social superior to his uneducated neighbours, outside his neighbourhood, he is an ordinary Tamil, an identity increasingly disparaged by the political atmosphere of the time.

If the final scene highlights Nadarajah's otherness, his tragic death is the result of accepting his ethnic identity as a fait accompli. Both Gunay, his Sinhala co-worker, and Simon cannot persuade Nadarajah to keep a low profile by avoiding the public sphere during anti-Tamil violence but his simplistic logic, that he is good to people and people, in turn, are good to him, is at odds with the irrationality of mob violence. And in light of his narrow escape in the café when Sushila saves him, Nadarajah's decision to leave the safety of his home cannot be blamed on his naivety, his underestimating of mob violence. Nor is his impetuosity a sign of 
defiance, a refusal to hide behind closed doors (as in the case of Rasa in Ernest Macintyre's Rasanayagam's Last Riot). Indeed, his illogical behaviour belies what Pradeep Jeganathan calls "tactics of anticipation," which he defines as "a repertoire of practices that are produced by Tamils given an anticipation of violence" (90). Similarly, after 20 years in Colombo, Nadarajah could very well anticipate anti-Tamil violence and develop a "repertoire of practices" but he chooses not to, which is illustrated in one particular scene. On the day he is killed, Nadarajah goes to work alone, as Gunay fails to show up at their usual meeting place. But then, we see Gunay waiting for Nadarajah at the train station. When Gunay explains that he can no longer accompany Nadarajah to work, the latter correctly assumes that is due to the violence sweeping through the city. Not surprisingly, Nadarajah accepts Gunay's selfishness graciously: "Your own life is more important than the life of another. I am not upset with you. I love you." If Gunay can abandon their friendship to preserve his own life and if his own life is actually more important than that of another, why does Nadarajah care so little for his own life? Why does he not apply this wisdom to his own life? The only meaningful interpretation available to us is that Nadarajah's repertoire of tactics is negated by his guilty conscience, which has not dissipated 20 years hence. His bigotry towards Rasan that leads to Thanga's suicide renders him complicit in her tragic death. His fondness for Wasanthi is an attempt to rectify this wrong. One could argue that following Thangamani's suicide, Nadarajah's life is spent atoning for that sin. His rash decision to go to work on the day of the riot is a form of suicide, the ultimate act of atonement.

Taken as a whole, however, Sunil Ariyaratne's filmic text vacillates between empathy and antipathy, identification and disidentification with the Tamil minority. Likewise, the film's finale is much more ambivalent than I have suggested. Nadarajah's violent death is depicted unapologetically and is vociferously mourned by three Sinhala characters: Simon, his wife, and his daughter. Ariyaratne's use of melodrama as the preferred narrative mode of the denouement is also a way of connecting with the typical consumers of Sinhala cinema who have a penchant for "sensational incidents and violent appeals to the emotions" (Jayamanne 94). ${ }^{9}$ Narrated using elements of melodrama, this final scene where an icon of the Sinhala screen, playing a Tamil character, is brutally

${ }^{9}$ Laleen Jayamanne argues, "the family melodrama is the one which has become dominant, if not the only, genre in the Sri Lankan cinema" (92). 
murdered by a Sinhala mob elicits profound sympathy for the minorities; so much.so that Sinhala audiences regarded the film as an unfair portrait of their community. ${ }^{10}$ In analysingSarungale, I have traced the film's inconsistent and contradictory stance towards Tamilness: the film's conflicting desire to both identify with Tamilness through characteristics shared by both communities and to further accentuate Tamils' "otherness" through invented or inflated notions of difference. This conflictual economy characterizing Sinhala-Tamil relations takes a new and different form in the 1990s in Gamini Fonseka's own filmic creation, Nomiyena Minisun.

\section{Indian Geopolitics and the Tamil Militant Movement}

The decade of the 1980s marks the rise of the cult of the soldier and Fonseka's Nomiyena Minisun, upon first glance, seems to contribute to that increasingly popular discourse. ${ }^{11} \mathrm{By}$ the $1990 \mathrm{~s}$, when Fonseka turns his cinematic eye once more to the ethnic conflict, it had escalated into open warfare and witnessed two Eelam Wars and seen India's direct involvement, both political and military. The South of Sri Lanka, too, had witnessed much violence and bloodshed in the form of the return of the JVPand its second armed rebellion against an authoritarian government. It is in this environment of unrelenting violence that Fonseka presents Nomiyena Minisun. These internal forces of conflict are compounded by a new geo-political dynamic, marked most stridently in the film by the entry of several Indian characters who compete for the film's visual space occupied by Tamils in Sarungale. As such in Nomiyena Minisun, Tamil identity is defined in contradistinction to North Indian identity, while the latter is represented as culturally contiguous to Sinhala identity, especially through the Indian origins of Buddhism. Fonseka reinforces this cultural link between the Sinhalese and North Indians through the hero of the film, Colonel Ranabahu Jayasundara of the Sri Lanka Army, who is married to an Indian woman named Madhu with whom he has a son named Bharat. Their marriage, however, is terminated when Madhu's father, a retired General in the Indian Army, takes her and Bharat back to India, citing growing anti-Indian sentiments in Sri Lanka. These events have taken place in the past

\footnotetext{
${ }^{10}$ In Cinamawen Nirupitha Janawargika Prashnaya, Jeevantha Dayananda excerpts remarks published by several filmgoers (18-19); these viewers bemoan the absence of Tamils' violence against Sinhalese and the paucity of virtuous Sinhalese who come to Nadarajah's rescue.

${ }^{11}$ For a related discussion, see de Mel 221.
} 
and are conveyed through a flashback facilitated by Ranabhu's Tamil servant, Subramaniam.

In the present, however, the narrative aligns itself with the soldiers' experience, especially as the aptly named Ranabahu, ${ }^{12}$ played by Gamini Fonseka, takes an Army Captain named Ranjith Bulankulame under his tutelage. Ranabahu's relationship with Ranjith parallels that of a father and son, a bond that fills the void left by Ranabahu's son, Bharat (whose name reinforces the intimacy proposed between the two nations). This filial substitution between Ranabahu's half-Indian and half-Sri Lankan son and a Sinhala soldier played by Gamini Fonseka's biological son, Damith Fonseka, underlines the putative cultural proximity between North Indians and the Sinhala people. That is, if Ranabahu's half-Indian son can be replaced by a Sinhala soldier, it suggests a tangible cultural and historical link between the North Indians and the Sinhalese. Indeed, the film is in part an attempt to repair the relationship between the Indian state and the Sinhala people, a historical tie undermined by the armed conflict and India's role in it. Contrary to this logic of reconciliation, however, the film is also highly separatist in imagining the Sinhalese as distinct from Sri Lankan Tamils and the Tamils in Tamil Nadu as distinct from North Indians. In other words, the film insinuates that the Sinhalese are culturally closer to North Indians than Dravidians; this is the film's suggested basis for political cooperation between the two governments, which had been at loggerheads in the late-1980s. Paradoxically, however, this does not prevent Fonseka from distinguishing "good" Tamil militants from "bad" and underscoring the commonalities between the Sri Lankan military and Tamil militants.

The film's preoccupation with the tension between the categories "Tamil" and "Indian" is made explicit early in the film when Ranabahu has a conversation with an Army General played by none other than the current President of Sri Lanka Mahinda Rajapaksa. Ranabahu inquires why he has been side-lined in operations against Tamil militants in the North of Sri Lanka. The General informs him that it is due to Ranabahu's "Indian connections." To this Ranabahu offers the following riposte: "India is a large country where numerous languages are spoken and it is home to many ethnic groups. The assumption that India is inhabited by Tamils is an ignorant notion." Ranabahu's Indian connections are a reference to

12 "Rana" means martial and "bahu" means hand, a suffix attached to names of many Sinhala kings, such as Parakramabahu and Vijayabahu. 
his Indian wife and child. In praising India's ethno-linguistic diversity, Ranabahu is also acknowledging his wife's non-Dravidian ancestry. His insistence on distinguishing Indian from Tamil in effect rehearses a popular trajectory in Sinhala nationalism: of tracing modern Sinhala identity to North India through the chronicled figure of Vijaya, who is supposedly from North India, while simultaneously excluding any Dravidian influence.

If caste is the red herring in Sarungale, its equivalent in Nomiyena Minisun is Fonseka's preoccupation with defending India. First, it is important to historicize Fonseka's peculiar stance in relation India; second, we will consider how Fonseka may defend the central government of India yet condemn Tamil Nadu. It is apparent that Fonseka's defence of India is a response to the sweeping anti-Indian sentiment prompted by India's covert and overt involvement in Sri Lanka's armed conflict from the early 1980s that culminated in the Indo-Lanka Accord of 1987. Then Indian Prime Minister Rajiv Gandhi's efforts in bringing the Sri Lankan government and the LTTE together, by force majeur, made Gandhi, and by extension India, a popular target amongst a large number of Tamils and Sinhalese. ${ }^{13}$ For the Sinhala political establishment, this was a time when deep-seated anxieties, of being federated with India, were triggered by India's unsolicited intervention. Thus, by adopting this pro-India stance, Fonseka who served as deputy speaker of parliament from 1989 through 1994 (during the making of Nomiyena Minisun), rejects the anti-Indian position prevalent at the time, a view maintained by his own President, Ranasinghe Premadasa. ${ }^{14}$ Though his position divorces Tamil identity from Sinhala and Indian identities, his curious stance on India goes against the prevailing political sentiment and is not unlike the radical position he adopts vis-à-vis the Tamil militant. But before we turn to militancy, let us consider Fonseka's grievance with Tamil Nadu.

In an important scene featuring Ranabahu and Madhu's father, the retired Indian General, Fonseka juxtaposes modern Indo-Lanka

\footnotetext{
${ }^{13}$ For an extended discussion of the Indo-Lanka Accord and the political maneuvers that took place behind the scenes, see Sankaran Krishna. Similarly, in August 2014, the publication of K. Natwar Singh's autobiography, One Life is not Enough, gives us a ring-side seat of the events leading up to the Indo-Lanka Accord, from an official Indian perspective.

${ }^{14}$ It is well known that President Premadasa even struck an agreement with the LTTE to successfully evict the Indian Peace-Keeping Force from Sri Lankan soil.
} 
givesmilitants a voice--one that does not merely echo hegemonic narratives of state propaganda. ${ }^{18}$

Arguably, the most balanced portrayal of a Tamil militant in Sinhala cinema is Param, a leader of one of the militant groups depicted in the film. During the fire fight in Mankulam, when the Army captures Param, he demands to be killed: "why don't you kill me? Officer, why the hell don't you finish me off?" Ranjith decides to spare Param's life proclaiming, "We are soldiers, not butchers." Later in the film when Ranjith falls into the hands of the militants, Param spares Ranjith's life to reciprocate the humane treatment he received as a captive. Towards the end of the film, before Ranjith is released to the Army through a prisoner exchange, Param makes a poignant statement: "Some day when this madness is over, if you and I should meet alive, you must allow me to return that favour." The favour he refers to is that Ranjith had given him a drink of water when he was first captured on the battlefield. Not only are the two men both physically impaired by the war--Param has a noticeable limp and Ranjith has prominent scars; this scene implies that despite the death and destruction that surround them, they have gained a deeper understanding of their mutually constituted identities, as actors in two ethno-nationalist narratives. For instance, in the scene where Param is captured by the Army and demands to be killed, both Param and Ranjith use an identical rhetoric to characterize each other. Ranjith views the militants as butchers; Param views the Army as a mercenary force fighting for pay, while he sees himself as fighting for his people, for Eelam. Ranjith's response that the Army is fighting for the country and the entire nation (mulu jathiyatama) is identical to Tamil nationalism espoused by Param, especially if the nation envisioned by Ranjith is Sinhala Buddhist. In other words, each side views the other in identical fashion, a commonality they come to recognize by the end of the film. Finally, by invoking the future, Param reveals his ability to transcend the insularity of the conflict. It suggests that even battle-hardened militants can dream of a normal life, free from war and violence.

Fonseka's attempt to give voice to the Tamil militant is further reinforced when Ranjith is taken prisoner by Param, who spares Ranjith's life and then insists that Ranabahu meet with him to

\footnotetext{
${ }^{18}$ Mohan Niyaz's Kalu Sudu Mal (2002), a film that can be placed in the same popular/commercial genre as Nomiyena Minisun, depicts Tamil militancy as having little or no redemptive qualities. A more recent example of this phenomenon is Boodee Keerthisena's Matha (2012).
} 
negotiate Ranjith's release and that of other POWs. The militants ask specifically for Ranabahu because he has a reputation as a soldier with a great regard for humanity. The following conversation underscores the insight that war and violence need not erase the common humanity that unites the two parties to the conflict.

Ranabahu: Param, do you think we can still trust one another?

Param: What do you think, sir?

Ranabahu: Well, I try not to lose faith in humanity.

Param: Then go ahead, sir; what is it you want?

Ranabahu: Param, I want my men back.

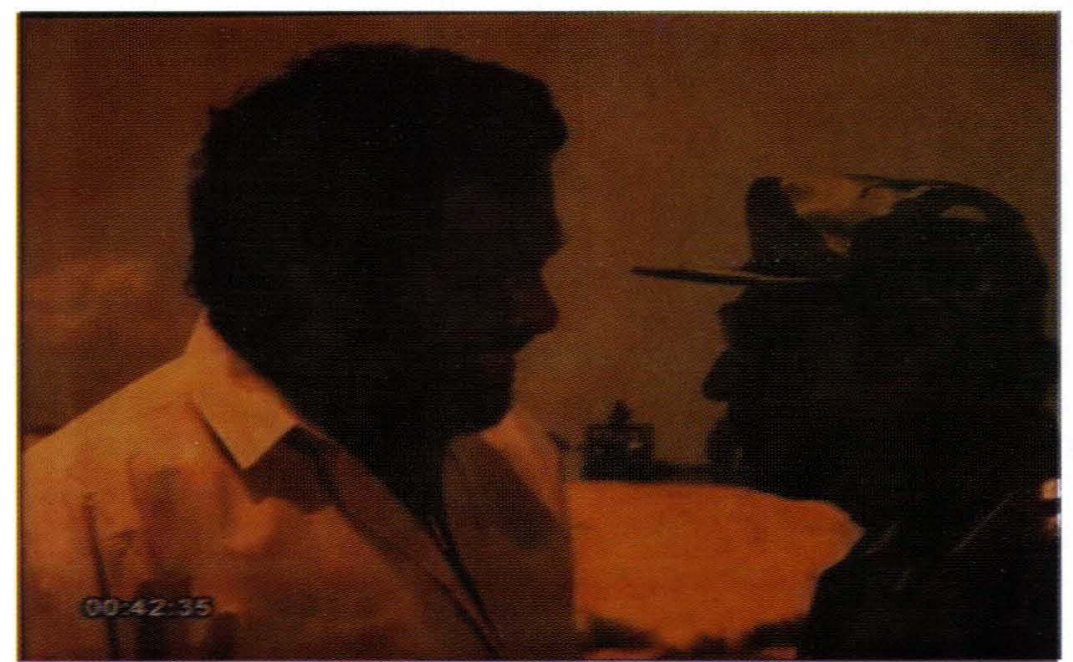

Figure 2: An affable exchange between Param and Ranabahu

Indeed the militants specifically identify Ranabahu with whom to negotiate because they trust him. The two characters in this scene do not define themselves through their affiliations as soldiers or as rebels, but as belonging to a more universal category, humans. This cosmopolitan perspective shared by the two adversaries is not confined to just one militant. Subsequently, when Param introduces Ranabahu to his superior, Major Krishnakumar speaks in Tamil and Ranabahu replies also in Tamil, before turning to English as a link language. The fact that Ranabahu speaks Tamil fluently identifies another point of unity between the state and non-state actors.

Krishnakumar: But we both understand English, don't we?

Ranabahu: Perhaps we can use it as a bridge, then, Major.

Krishnakumar: Let us cross it then, Colonel (they shake hands). 
This conversation between two men representing the top brass of two warring sides, in a conflict originating in the language rights of the Tamil minority, proposes that the English language may play a centripetal role in uniting the different linguistic communities in Sri Lanka. Moreover, by invoking a common language, the film signals other ways of finding common ground. This scene, as well as others in this sequence, centres on bridging differences, not just linguistic but political and cultural as well. The mutual respect (and trust) displayed between the militants and Ranabahu underscore the path the film advocates for the resolution of the armed conflict. Thus it is through Param's character (whose name means supreme being) and that of Major Krishnakumar that Fonseka humanizes the Tamil militant-a feat that no other Sinhala film has achieved either in mainstream Sinhala cinema, or in the so-called Third Revolution. ${ }^{19}$

Alas, such radical politics are not free from ambivalence, as not all Tamil militants envisioned by Fonseka have redemptive potential. While a majority of the film is concerned with Param's militant group, it also reveals another unspecified group that represents its antithesis. While Param's is the voice of reason, the other group of militants depicted in the film has neither a name nor a voice and are reduced to stereotypical "terrorists." They ruthlessly murder an Indian doctor and his wife who nurse Ranjith while he recovers from injuries suffered during the battle in Mankulam but the narrative provides no explanation for their actions. Towards the end of the film, as Colonel Ranabahu negotiates with Param's militant group for a prisoner exchange, another group of militants attack Param's camp. Again, the narrative fails to explicate their motivations. As evident from these two scenes, Nomiyena Minisun reveals a striking silence regarding the differences between militant groups. In fact, when Ranabahu questions as to why Param's group has brought arms to a peaceful negotiation, the Major explains "We are armed but not against you, Colonel. There are five other group out there operating independently." There is some irony in his remark in that Param's group sees the other, nondescript militant group as "operating independently" from them, while the state sees Param's group as attempting to become independent from the

\footnotetext{
${ }^{19}$ According to Robert Cruz, this term was first used by Lester James Peiris. Narratives in this category of alternative films rarely depict Tamil characters; they are even less likely to depict Tamil militants. One exception would be Sanjeewa Pushpakumara's Flying Fish (2011), which despite offering a balanced critique of Tamil and Sinhala militancy can only imagine the former through the lens of conscription and extortion.
} 
nation at large. Evidently, the proliferation of militant groups is to blame for the abrupt end to the peaceful negotiation and the potential for dialogue between the State and Param's militant group. Nonetheless, the battle that ensues between the two militant groups presents Param with an opportunity to become the hero when he helps Ranjith escape to safety. It is during this battle between "good" militants and "bad" militants that the latter kills our "immortal hero," Ranabahu, further demonizing the "bad" militants.

Fonseka's preoccupation with Tamil militants, both good and bad, does not take place in a historical vacuum. Nomiyena Minisun both reflects the political landscape of the time period while it also anticipates the future wherein militants responsible for death and destruction on a large scale can successfully crossover from the battlefield in to the political mainstream free from consequences. Fonseka's conflicting narrative of a film framed by Sinhala nationalism (i.e., the heroism of the Sinhala soldier that Prasad Gunawardene recalls), which also humanizes the "enemy," the Tamil militant, may help us understand the competing political developments of the last two decades. In fact, over the last three decades the Sri Lankan state has witnessed a host of non-state actors who have taken up arms against it. While the war between the LTTE and the State dominates most discussions of political violence in modern Sri Lanka, there is little analysis of the varied category called "militant Tamil," presumed to be a fixed category, linked to the simplification that all armed non-state actors belong to a permanent and clearly defined category.

Not unlike the timeframe of Nomiyena Minisun, which concludes in 1989 with Ranabhu's funeral, the figure of the "virtuous" Tamil militant emerges in the late 1980s, following the Indo-Lanka Accord when several groups of Tamil militants were forced to enter the political mainstream. To cite two brief examples, Douglas Devananda of Elam People's Democratic Party (EPDP) 20 and Varatharajah Perumal of the Eelam People's Revolutionary Front

\footnotetext{
20 In the late 1980s People's Liberation Organization of Tamil Eelam (PLOTE) and Eelam People's Democratic Party (EPDP) aligned themselves with the government of Sri Lanka, which in turn allowed them to carry firearms in Colombo for selfdefense and even paid its cadres monthly salaries. As D.B.S. Jeyaraj (2001) notes, Devananda escaped from prison in Sri Lanka and fled to India in 1986 and then fled India on bail and returned to Sri Lanka in 1990. To this day, there is an outstanding warrant for his arrest in Tamil Nadu.
} 
(EPRLF) were at one time leaders of their respective militant groups, who under attack from the LTTE sought the protection of the government and the IPKF. Although In 1988, Perumal became the first Chief Minister of the merged North-East Province, his political ascent was short-lived; Douglas Devananda, on the other hand, has risen to the position of a cabinet minister and continues to function as a core-member of the UPFA, the coalition currently in power.

Since Fonseka's film is narrated from the point of view of the Sinhala military establishment, one expects that its portrayal of Tamil militancy would be antithetical to its own self-representation. That is, we can expect the "enemy" of the heroic Sinhala soldier to be depicted in starkly negative terms. In fact, in the aforementioned scene where Ranjith calls Param a butcher does just that. The rest of the film, however, reveals how a "butcher" can evolve into a likable character with whom the audience can identify. Unlike former militants Devananda and Perumal who abandoned militancy at a much earlier stage in the conflict, and are therefore less maligned, the case of Vinayagamurthy Muralitharan (a.k.a. Colonel Karuna Amman) represents how a "butcher" can be absorbed into the political mainstream over the course of a few years. While there are many examples of the State's malleable position towards militants, few stand up to the metamorphosis of Colonel Karuna. ${ }^{21}$ Even if such political "mutations" can be dismissed as traitors to the Tamil cause exploited by the government for political gain ${ }^{22}$ or a form of tokenism meant to defer the transfer of real power to the minorities, what is curiously absent is the dissenting voice of Sinhala nationalism. Quite ironically, the most vociferous criticism of the government's integration of militants into the political mainstream has come from Eelamists in the diaspora, ${ }^{23}$ and not as much from the Sinhala nationalist groups, such as the Jathika Hela Urumaya (JHU). ${ }^{24}$

\footnotetext{
21 It is well known that Karuna was behind the cold-blooded murder of approximately 600 unarmed police officers in June 1990 when then President Premadasa instructed police posts in the Eastern province to surrender their weapons to the Tamil Tigers. To reward his contribution to the government campaign against the LTTE, he was made Member of Parliament in 2008 and Cabinet Member in 2009.

22 See Karthigesu Sivathamby.

${ }^{23}$ See, for instance, "Karuna's wife says her husband betrayed the Tamil community."

${ }^{24}$ In the run up to the Presidential Election of 2015, which was anticipated for many months before it was officially announced in November, 2014, we have
} 
Indeed, the reincarnation of former combatants as new stakeholders in the government has challenged static definitions of militants, an identity often conflated with "terrorists." However, the route back to mainstream politics taken by the aforementioned militants does not apply to all Tamil militants. In fact, several thousands of LTTE cadres who survived the final battle took a different path before returning to civil society. When the war ended in May 2009, government forces systematically separated "dangerous" elements of the militant movement from the rank and file (Colman); financed by some of the same European nations that accused Sri Lanka of human rights violations, this rehabilitation program adopted by the state was intended to reform militants and help them return to civil society (Hettiarachchi) but also to identify and contain future threats to state power. ${ }^{25}$ However, there is little critical debate about the arbitrary distinction made between LTTE defectors, like Colonel Karuna, and LTTE combatants who surrendered or were captured at war's end. The obvious question is why wasn't a similar program of deradicalization required for Douglas Devananda, Karuna Amman, Sivanesathurai Chandrakanthan (a.k.a. Pillayan) and their cadres? These and others ex-combatants played leading roles in different militant groups. Even militants who surrendered to the army in the waning hours of the conflict were subject to isolation and interrogation to determine their eligibility for rehabilitation. This was, no doubt, a seemingly contradictory, illogical position taken by the state, and illustrates its ambivalent attitude towards the Tamil militant. ${ }^{26}$

Likewise, Fonseka's Nomiyena Minisun provides an uncanny parallel to the Sri Lankan state's ambivalent position towards Tamil militants. On the one hand, Param's character represents the potential to redefine the Tamil militant as an ally; however, Fonseka does not extend this conciliatory gesture to all militants depicted in his film. While Param's is the voice of reason, the other group of militants depicted in the film has neither a name nor a voice and are reduced to stereotypes. In fact, they. are relegated to the category

witnessed nationalist parties like the JHU and opposition parties like the JVP call into question the decriminalization of Tamil militants.

25 The rehabilitation of LTTE cadres, child soldiers in particular, began years before the war ended but it entered a new accelerated phase in 2009.

${ }^{26}$ Quite ironically, this contradiction is absent not only from official discourse (i.e., Hettiarachchi) but it eludes the Tamil nationalists in the diaspora as well. See "Sri Lanka's 'Rehabilitation' of the Liberation Tigers of Tamil Eelam." 
"of ruthless terrorists" in the words of Prasad Gunewardene merely because the film fails to represent their perspective and narrate their story. It seems, then, that in recuperating militants in an armed conflict, we can only narrate one story at a time. Nomiyena Minisun tells the story of Param's group at the expense of other combatants. Thus the film's characterization of the other militant group as ruthless and irrational is comparable to the official discourse about the LTTE at war's end. ${ }^{27}$ While the string of militants who joined the political mainstream illustrates the state's ambivalence towards militancy, we reach the limits of that ambivalence in the face of LTTE's defeat. The state's malleability during the war does not persevere until war's end. In other words, the state's ambivalence had a political purpose, the defeat of the LTTE; once that goal is attained or nearly attained, there is no further incentive for it to maintain its permissive stance. That is the realpolitik of the state's ambivalence towards militant movements.

In this paper, I have highlighted the ambivalent relationship between two filmic texts and its representation of violence: in the first instance, I considered Sunil Ariyaratne's ambivalent response to communal violence and in the second, I examined Gamini Fonseka's ambivalence towards the Northern Tamil subject, especially in relation to Tamil militancy. The purpose of this exercise was meant to expose the risks and rewards of the politics of paradox that is at the heart of Sri Lankan political life. The alltoo-real risk of an ambivalent attitude towards communal violence is plain to see in contemporary Sri Lanka, especially in the wake of the anti-Muslim riots in Aluthgama in June 2014. The pathos evoked at the melodramatic conclusion of Sarungale by no means rectifies the problem of defining the Sinhala-Tamil communities through a conflictual economy, in which Tamils are retrograde and Sinhalese are progressive and "good hearted." As for Tamil militancy, although the state's malleable position has helped de-criminalize ex-combatants and ushered them into the political mainstream, a far better alternative to the fate of enemy combatants languishing in Guantanamo Bay, this liberal recuperation of Tamil militants happens at the expense of a core constituent in the Tamil militant movement, the LTTE; at present, they represent a proscribed narrative in the Sri Lankan armed conflict, even as its former members enjoy the privileges of the ruling political elite. Nomiyena Minisun reflects this contradiction first by its exclusion of Northern

${ }^{27}$ To characterize the final stage of the war between the Government and the LTTE a "humanitarian operation" proves the extent to which the latter were demonized. 
Tamils from the national imaginary and second by recuperating one group of Tamil militants over others.

At the end of Fonseka's film, Param is a defäcto hero, for saving Ranjith's life in the battle between "good" militants and "bad" militants. Alas, it seems that Param's goodness is contingent on the vilification of the other group of militants. This is how, in contemporary Sri Lanka, ex-militants have risen to eminence in the political sphere, while at the same time, the mere remembrance of dead Tamil Tigers is an act of treason. By enforcing this double standard, the state refuses to acknowledge its inconsistent, illogical stance. This paradoxical position regarding militants can only produce limited rewards. It may have helped end the military conflict but, perhaps, it is a matter of time until the suppressed and excluded other (in the form of the LTTE) returns with a vengeance.

\section{References}

Bahabha, Homi. "The Other Question: Stereotype, Discrimination, and the Discourse of Colonialism." The Location of Culture. New York: Routledge, 1994.

Colman, Padraig. "Rehabilitating the Tigers." Le Monde Diplomatique. October 2009. Web. 29 August 2014.

Cruz, Robert. "The Forms of Contentious Content: A Reflection on Asoka

Handagama's This is My Moon." Cinesith 1 (2001): 23-32.

Dayananda, Jeevantha. Cinemawen Nirupitha Janawargika Aragalaya (Cinematic Representations of the Ethnic Conflict). Colombo: Sarasavi Publishers, 2008.

De Alwis, Ananda Tissa. "Eka Hiru Eliya Yata Apa Athara Minis Suwanda Wedikisiwak Kohida?" Sarasaviya 23 March 1979: 15. Print.

De Mel, Neloufer. Militarizing Sri Lanka: Popular Culture, Memory and Narrative in the Armed Conflict. New Delhi: Sage, 2007.

Gunasinghe, Dayasena. "Miniskama Kiyana Sarungale." Silumina 23 March 1979. Print.

Gunasinghe, Newton. "The Open Economy and Its Impact on Ethnic Relations in Sri Lanka." Economy, Culture, and Civil War in Sri Lanka. Eds. Deborah Winslow and Michael Woost. Bloomington and Indianapolis: Indiana University Press, 2004. 99-114.

Gunewardene, Prasad. "Gamini Fonseka: A Man of the Troops." Daily News. 30 September 2008. Web. 30 November 2014. 
Harding, James Martirt Adorno and "A Writing of the Ruins": Essays on Modern Aesthetics and Anglo-American Literature and Culture. Albany: SUNY Press, 1997.

Hettiarachchi, Malkanthi. Sri Lanka's Rehabilitation Program: The Humanitarian

Mission Two. Colombo: Department of Government Information, 2014.

Jayamanne, Laleen. Toward Cinema and Its Double: Cross-Cultural Mimesis. Bloomington and Indianapolis: Indiana University Press, 2001.

Jeganathan, Pradeep. "In the Shadow of Violence: 'Tamilness' and the Anthropology of Identity in Southern Sri Lanka." Buddhist Fundamentalism and Minority Identities in Sri Lanka. Eds. Tessa J. Bartholomeusz and Chandra R. De Silva. Albany: SUNY Press, 1998. 89-109.

Jeyaraj, D.B.S. "The Douglas Devananda Phenomenon." The Sunday Leader. Leader Publication, 18 November 2001. Web. 13 August 2014.

"Karuna's wife says her husband betrayed the Tamil community." Global Tamil News. n.p. 23 July 2009. Web. 25 August 2014.

Krishna, Sankaran. Postcolonial Insecurities: India, Sri Lanka and the Question of Nationhood. Minneapolis: University of Minnesota Press, 1999.

Obeysekera, Gananath. "The Origins and Institutionalization of Political Violence." Sri Lanka in Change and Crisis. Ed. James Manor. London: Croom Helm, 1984.153-174.

Silva, Kalinga Tudor. Caste Discrimination and Social Justice in Sri Lanka: An Overview. New Delhi: Indian Institute of Dalit Studies, 2009.

Singh, K. Natwar. One Life is Not Enough: An Autobiography. New Delhi: Rupa Publications, 2014.

Sivathamby, Karthigesu. "Opinion: Tamil Regionalism: Historical Causes and the Crocodile Tears." Being a Tamil and Sri Lankan. Colombo: Aivakam, 2005. 165-171.

Tambiah, S.J. Sri Lanka: Ethnic Fratricide and the Dismantling of Democracy. Chicago: University of Chicago Press, 1986.

Vittachi, Tarzi. Emergency '58: the Story of the Ceylon Race Riots. London: Andre Deutsche, 1958.

Wickramasinghe, Nira. Sri Lanka in the Modern Age: A History of Contested Identities. Colombo: Vijitha Yapa Publications, 2006 